Marzena Szczepkowska Uniwersytet Kardynata Stefana Wyszyńskiego w Warszawie

\title{
Mary as a Sign of God's Mercy Toward Women and the World
}

In the plan of God's Mercy, Mary plays a unique and irreplaceable role as the Mother of Jesus and as a sign of God's Mercy towards all women and the entire world. As a sign, Mary significantly resembles other women both because of her sex and because of Jesus' attitude towards the women he met. This attitude is so clear that it conveys that women experience God's mercy in a particular way and that they have a specific vocation in the world. Particular chapters of the Bible tell us about Mary as a sign of Divine Mercy, about God's Mercy toward women, and about women as the ones who bring Divine Mercy to the world.

Key words: Mary, Mother of God, Divine Mercy, Incarnation, feminine genius, motherhood, biblical exegesis.

\section{Introduction}

This article considers the relationship between Mary and femininity from the perspective of Divine Mercy. In becoming the Mother of God, Mary played a key and unique role in God's plan of salvation. Despite Mary's uniqueness, however, she is similar to the other women based on her sex and on Jesus' attitude toward her. Jesus' unambiguous attitude toward women reveals that women experience Divine Mercy in a particular way and that women have a specific vocation in the world. St. John Paul II said, "This Marian dimension of Christian life takes on special importance in relation to women and their status. In fact, femininity has a unique relationship with the Mother of the 
Redeemer." ${ }^{1}$ This study analyzes biblical texts using the hermeneutic of faith and the theological principle of Biblical unity by comparing relevant biblical texts to the observed data.

\section{Mary as a Sign of Divine Mercy}

Jesus' entire earthly life, which "in a certain sense, is mercy" ${ }^{2}$ itself, is connected to Mary, so much so that it is even possible to assert that Divine Mercy is with her from the very beginning of the creation of man.

\section{The First and Second Creation of Man}

God's creation of man was his first act of mercy toward humanity; for, he created man and woman in his image and likeness as rational, free, and sexual beings. The idea that human sexuality ushered humanity into the reality of the Incarnation from the beginning is consistent with the Franciscan school of thought that upholds that, in God's providential plan, the Incarnation is immanently connected with the creation of man and not, as the Dominican school of thought says, with Adam and Eve's sin itself, which proved to be a blessed fault. ${ }^{3}$

Since the second century, St. Justin Martyr called Mary the second Eve and Jesus the second Adam. This second creation of man in the persons of Jesus and Mary is the appropriate paradigm of humanity. When interpreted anew, this paradigm provides a cultural example that responds to the needs of our day and this sign of Mary expands our perspective on women.

\section{Christocentrism}

The Mother of God leads to a Christocentric anthropology in which the perception of women through Eve gives way to the perception of women through Mary. The sign of Mary is fully integrated into a Christological image of the world. In his plan to draw man closer to himself and in his plan of salvation, Christ set aside a special place for Mary. Therefore, it is possible to say that not only Mary, but also and firstly Jesus Christ and His relationship with His Mother, are the

John Paul II, Redemptoris Mater, 46. Hereafter abbreviated RM.

John Paul II, Dives in Misericordia, 2. Hereafter abbreviated DM.

See W. Chrostowski, "Ludzka cielesność jako obraz Boga," Collectanea Theologica 70, no. 4 (2000): 5. 
hermeneutic key that explains femininity. According to this key, the paradigm of femininity realized in the person of Mary concerns every woman to a certain extent and in a certain way. Understanding and accepting Mary's example makes it possible to rebuild the identity of women which was destroyed as a result of original sin. St. John Paul II left numerous documents, particularly his encyclicals Redemptoris Mater and Evangelium Vitae and his letters to women Mulieris Dignitatem and A Ciascuna di Voi, which greatly inspire reflection on the essence of femininity as it is understood in the broad context of salvation history. Since the Mother of God is an inextricable component of this history, Adrienne von Speyr's assertion, "In Mary resides the idea of the perfect human being, an idea that God had when he created the first human being. Thus Mary is in fact not the second but the first Eve; she is the one who did not fall and who sees how the second Eve does fall," is well-founded.

Although the first creation of man ends with his fall, Jesus nevertheless extends a helping hand to humanity and shows the way back to the Father's house both through the sign of the Immaculate who accompanies the act of the second creation and through conversion.

\section{Conversion}

Man's relationship with God exalts and transforms him. In order to encounter man, God lowers himself (kenosis). In order to encounter God, however, man must become exalted according to Mary's example. This takes place through the process of conversion. This, then, begs the question: Was it necessary for Mary to convert? The answer to this question depends on how one defines the term "conversion."

Conversion is commonly assumed to mean turning away from the wrong path in order to enter upon the right path of life. According to this definition of conversion, Mary did not need to convert. However, if one understands conversion as a change from his old way of thinking to thinking according to Christ, then Mary, as Christ's first follower, also walked the way of conversion-a path that, as the Gospels repeatedly affirm, was undoubtedly very demanding and often painful. From a human point of view, Mary's life was not easy: she endured the real threat of being stoned after she conceived Jesus; she gave birth in a very uncomfortable setting (a cave or room in a stranger's home); she had to escape with Joseph and the baby Jesus to Egypt, knowing that

Adrienne von Speyr, Mary in the Redemption (San Francisco: Ignatius Press, 2012), 20. 
the infants Jesus' age had been massacred; she followed alongside her Son, the Messiah, and saw how his teaching evoked the opposition of many of the authorities; and she witnessed her Son's cruel torture and brutal death on the cross. Yet, we know for certain that Mary was the first to experience Divine Mercy and a spiritual relationship with Her Son in an extraordinary way. Divine Mercy does not necessarily make life easier and less burdensom, but it does makes it possible for human life to be united with God. For this reason, the mysteries of Mary's life: the Immaculate Conception, her Divine Motherhood, her Perpetual Virginity, the deep (but not easy) mutual understanding she shared with her Son, as well as her process of conversion are simultaneously the mysteries of Divine Mercy that elevate man to the dignity of being a child of God.

The humanity revealed in Jesus and Mary became a new beginning for man and the world. Cardinal Joseph Ratzinger points out that the grace that accompanied Mary's conception is indeed a personal grace in the sincerest and deepest meaning of the word. It does not, however, draw attention to Mary herself because she did not even exist at the time. Rather, it sheds light on the mystery of Divine Mercy, which elevates and exalts man. ${ }^{5}$ As St. John Paul II once said: "mercy is manifested in its true and proper aspect when it restores to value, promotes and draws good from all the forms of evil existing in the world and in man." 6

\section{The Renewal of Relationships}

Man's relationship with God, which was disturbed through original sin, was completely renewed in Mary. It is even possible to argue that Divine Mercy touched this relationship most fully. Therefore, an individualistic approach is insufficient to explain the question of the Mercy that God showed Mary. All the mysteries of the Blessed Mother and her Son's life are relational in character: the Annunctiation, Incarnation, Visitation, Birth of Christ, Mary's joy, and her suffering with Christ. In addition, contempory theological thought strongly emphasizes Mary's relationship with the Holy Spirit. On the one hand, Scripture emphasizes Mary's freedom and free will in relation to God, and, on the other hand, the union between Mary's will and the Holy Spirit's will. Both St. John of the Cross and St. Maximilian Kolbe noted many

See. M. Masciarelli, Znak Niewiasty: Maryja w teologii Josepha Ratzingera (Cracow: Wydawnictwo eSPe, 2008), 27.

$D M, 6$. 
times that: "the Immaculate's will was always in accordance with God's will. Mary always carried out the will of the Holy Spirit who resided within her."

There are many ways to describe the essence of the relationship between the Mother of the Lord and the Holy Spirit. For example, the Italian theologian Domenico Bertetto speaks about the synergy between Mary and the Holy Spirit; the Fathers of the Second Vatican Council as well as Popes Paul VI and John Paul II call Mary the Tabernacle, Sanctuary, and Temple of the Holy Spirit; and Orthodox theologians were the first to consider Mary an image and Icon of the Holy Spirit. Sergei Bulgakov claimed that Mary is "completely transparent to the working of the Holy Spirit," and he named her the "Hipostatic Revelation" of the Spirit. Alexander Schmemann considered "the archetypal relationship between Mary and the Holy Spirit," which means that the nature of Holy Spirit himself is revealed in his relationship with Mary. ${ }^{8}$ In this sense, St. Maximilian Maria Kolbe went farther in his description of the intimate relationship between Mary and the Holy Spirit, arguing that "the Most Holy Mother of God exists so that we might know the Most Holy Spirit better." She is a "kind of embodiment of the Holy Spirit." 10 St. Maximilian's statements resonate with Paul Evdokimov's assertion that Mary is "ontologically united with the Holy Spirit." "If, therefore, Mary is as closely united with the Holy Spirit as modern theology asserts, then the sign of Mary (in relation to God and man) is not just an example, but also an issue that opens up new areas of exploration that may have significant implications for many fields of theological research.

In this modern age of numerous anthropological heresies and Easter philosophies' fascination with human abilities, focusing on the irreplacable purpose of relationships in Christanity can prevent man

$7 \quad$ See G. M. Bartosik, Mediatrix in Spiritu Mediatore: Pośrednictwo Najświętszej Maryi Panny jako uczestnictwo w pośredniczacej funkcji Ducha Świętego w świetle teologii wspótczesnej (Niepokalanow: Wydawnictwo Ojców Franciszkanów, 2006), 380-381.

Ibid, 380-393.

J. A. Książek, W. K. Kaczmarek, and J. R. Bar, eds. Konferencje świętego Maksymiliana Marii Kolbego, no. 103 (Niepokalanow: Wydawnictwo Ojców Franciszkanów, 1983), 169 in G. M. Bartosik, Mediatrix in Spiritu, 399. Hereafter abbreviated KMK.

KMK, no. 311, in G. M. Bartosik, Mediatrix in Spiritu, 406.

P. Evdokimov, "Duch Święty i Matka Boża," in Prawosławie II: Teksty o Matce Bożej 8, eds. S. C. Napiórkowski and H. Paprocki (Niepokalanow: Wydawnictwo Ojców Franciszkanów, 1991), 125, in G. M. Bartosik, Mediatrix in Spiritu, 406. 
from giving into the temptation to practice religious syncretism and harmful individualism. Mary's close relationship with the Holy Spirit also shows the way to the Church's spiritual renewal. This renewal should take into consideration Mary's presence, since she not only cooperated with the Holy Spirit, but also invoked Him and is most closely united with Him. ${ }^{12}$

\section{Divine Mercy Toward Women}

Ratzinger believes that the question of Mary is a question of Christianity. The woman of Nazareth makes it possible to transmit an entire array of principles to female elements in the world and to help answer numerous anthropological questions, including: "Who is woman?" and "What is her theological significance?"13 Servant of God Joseph Kentenich believed that every woman is a model of Mary, while Heinrich Koster presented the main features of femininity contained and renewed in Mary's example. ${ }^{14}$ Similarly, other great theologians such as Hans Urs von Balthasar, the Swiss mystic Adrienne von Speyr, Karl Rahner, Mathias Joseph Scheeben, Edith Stein, and Paul Evdokimov adopted a similar train of thought in Mariology. ${ }^{15}$

\section{Christ's Exemplary Attitude Toward Women}

Jesus Christ's attitude toward women was particularly challenging not only for the Jews but also for early Christians. Jesus' treatment of women exceeded the social norms for men at the time and remains an intellectual and spiritual challenge up to today. Father Joseph Kentenich believed: "Whoever wants to save the modern world must restore the proper ideal of femininity." 16

Jesus treats women very mercifully not only because women at that time were categorized as socially handicapped and deprived of many rights, but also and above all because the proper understanding and treatment of women is essential to understanding the meaning of the

$12 \quad$ See G. M. Bartosik, Mediatrix in Spiritu, 407.

$13 \quad$ See M. Masciarelli, Znak Niewiasty, 147.

14 See taken from A. Kostka, "Niepokalana-Kobiecość na nowo pisana," Kobieta w Kościele i w Społeczeństwie: Studia i Materiaty Wydziatu Teologicznego Uniwersytetu Ślaskiego w Katowicach, no. 78 (2014): 47.

15 See A. Kostka, Rozkwitnać petnia barw: Duchowość kobiety w Ruchu Szensztackim (Swider: 2008), 80.

16 J. Kentenich, Ideat kobiety: Stereotyp czy pociagajacy wzorzec (Otwock-Świder: Wydawnictwo Apostolicum, 2013), 23. 
question of the Kingdom of God. Jesus lived in a patriarchal time and society where women were neither allowed to make financial decisions nor to decide for themselves. From the beginning of Christian thought, the concept of human rights and of the person took a long time to be formulated. It was not until 1891 that these concepts were clearly expressed in the first papal declaration on human rights, the Encyclical Rerum Novarum. ${ }^{17}$ The rights of women, however, exercised in their right to vote, were not internationally acknowledged and upheld until the twentieth century. In Poland, women were granted the right to vote in 1918, while in Switzerland women could not legally vote until 1971. However, in the words of Fr. Jacek Salij, "Obviously, Christianity is not, nor ever has been, a social movement that strives for the equality of slaves and women with men. Rather, it is the message of God's mercy toward us all. The Church was not concerned with dismantling existing unjust structures when it proclaimed from the outset the fundamental equality between men and women, free men and slaves. The Apostolic Letters teach us how to externally adapt to these structures. The Church dismantled these structures from within by persitently proclaiming that all men are not only equal before God, but that God especially loves the weak and the lowly."18 At the time of Jesus, women undoubtedly were among the most vulnerable members of society. For example, a father could give his underaged daughter away in marriage without her consent. In turn, he would receive money from his daughter's fiancé. Once under the control of her husband, the young woman had to be completely obedient to him and address him as rab or ba`al, which is how a slaves addressed their masters. Only men were privileged to study the Torah. ${ }^{19}$ Living at the same time as John the Apostle, Rabbi Eliezer wrote: "Whoever teaches his daughter the Torah teaches her to commit iniquity," and "It is better to burn the Torah than to entrust it to a woman." 20 In light of this androcentic reality, it is clear how Jesus' attitude toward women, while scandalous to the Jews of the time, was great news.

17 See H. Skorowski, "Prawa człowieka," Stownik Społeczny, ed. B. Szlachta (Cracow: Wydawnictwo WAM, 2004), 967.

18 J. Salij, “Chrześcijański antyfeminizm,” W drodze 343, no. 3 (2002): 125.

19 SeeR.Egger-Wenzeland C.Kreinecker, "Kobieta/Żona," NowyLeksykon Biblijny, eds. F. Kogler, R. Egger-Wenzel, and M. Ernst (Kielce: Wydawnictwo Jedność 2011), 353; R. de Vaux, Instytucje Starego Testamentu (Poznan: Wydawnictwo Pallottinum, 2004), 37; and T. Brzegowy, Pisma Mądrościowe Starego Testamentu (Tarnow: Wydawnictwo Diecezji Tarnowskiej, 2007), 148-149.

20 P. Ketter, Chrystus a kobiety (Warsaw: Drukarnia Wydawnictwa Ks. Jezuitow, 1937), 60 . 
Jesus not only trusts women, which is clear in the Incarnation (he was conceived in a woman's womb), but he also entrusts to women the main truths of salvation such as the Resurrection and the fact that he is the Messiah. Jesus is not afraid to enter into relationships with women, as is evident in his friendship with Martha and Mary, whose home was a place where he could rest and relax. There was a special bond between Jesus and the women he chose-a bond he was not afraid to establish and sustain. He was not afraid of their feelings because he knew that their hearts were capable of a pure and selfless response. Nothing in Jesus' life was coincidental. It is not a coincidence that, in his human form, Jesus was a man and, as such, a model not only of humanity but also of masculinity. The Rabbi of Nazareth's uncompromising teaching on marriage, his encounter with the woman caught in adultery, and his setting her free by pointing out male lust as a source of moral evil makes woman a subject protected by the law established by the Supreme Lawmaker: "But I say to you, everyone who looks at a woman with lust has already committed adultery with her in his heart" (Mt. 5:28). The problem of desire in man's relationship with woman is very important, and perhaps even crucial; for, as Pope John Paul II observes, "lust [...] changes the very intentionality of the woman's existence 'for' man. It reduces the riches of the perennial call to the communion of persons, the riches of the deep attractiveness of masculinity and femininity, to mere satisfaction of the sexual 'need' of the body." 21

Until the Second Vatican Council, the idea of women's subordination to men was accepted in the culture in the teachings of the Church. As such, people did not fundamentally oppose it. Up until then, Scripture on this topic had been subject to false philosophical ideas that regarded women as the weaker sex and a simplistic methodology that did not distinguish between historical content and timeless theological meaning.

\section{The Need to Update Biblical Interpretations}

Theologian who seek to show how biblical texts are the actual and living Word of God acknowledge the need to know and understand the meaning of these texts more deeply. In some cases, this means that theologians must update the meaning of certain biblical texts. The Magisterium of the Church is of great help in this difficult task.

$21 \quad$ John Paul II, The Redemption of the Body and the Sacrament of Marriage (The Catholic Primer: 2006), 110. http://www.catholicprimer.org/papal/theology_of_ the_body.pdf 
To fully uncover God's mercy toward women, it is necessary to reflect on many biblical texts, especially Genesis 2-3 and St. Paul's writings.

Genesis 2-3

The writings of St. Pope John Paul II are an invaluable guide to understanding the Book of Genesis. Up to 23 of the 130 catecheses that Pope John Paul II gave during his Wednesday audiences from 1979 to 1984 pertain to the Book of Genesis. As this study follows in the footsteps of this great guide, it is necessary to explain two particular biblical passages:

1) "The LORD God said: It is not good for the man to be alone. I will make a helper suited to him" (Gen 2:18).

This is the beginning of the second account of creation, even though chronologically it is the first. With regard to this passage, Mary Healy, an American Bible scholar, comments: "We should note that helper in this verse (ezer in Hebrew) does not mean 'cook, laundress, and scullery-maid.' After all, it is God who is most often called our 'helper' (see, for instance, Exodus 18:4; Psalm 33:20). Rather, the helper the man needs is someone who can remind him of and help him to fulfill the deepest purpose of his life: that is, to love. In other words, the man needs the woman in order to be fully human, just as the woman needs the man." 22

Unfortunately, over the centuries, the help that God gives man has been understood instrumentally as a kind of service. In the biblical sense, however, "help" actually means support given to and even rescue of the whole person: his intellect, his heart, and his body. In this matter, which is essential to human life, one should not fall into the error of reductionism: "the woman must 'help' the man - and in turn he must help her - first of all by the very fact of their 'being human persons." ${ }^{23}$ Imparting help (ezer) requires acceptance, or receptivity, which is openness to all relationships, even to God himself. John Paul II says: "The concept of 'help' also expresses this reciprocity in existence, which no other living being could have ensured." ${ }^{24}$

God Himself, in the Person of Jesus Christ, did not hesitate to receive help from the woman whom he chose, Mary of Nazareth. As a true Mother, she not only cared for her Son, but also taught, raised, and admonished him.

22 M. Healy, Men and Women are from Eden, E-Book, Kindle (Ohio: Servant Books, 2005) 2008, 23. 
2) "Yet your urge shall be for your husband, and he shall rule over you" (Gen 3:16).

This curse of original sin that God Himself spoke has often been regarded as the norm for conjugal life, and not the result of sin. Consequently, women have been treated terribly, and heretofore the patriarchal model of the family has been the only one. This situation distorted the true image of Divine Mercy towards women and gave rise to legitimate protest. John Paul II, however, cautioned: "even the rightful opposition of women to what is expressed in the biblical words 'He shall rule over you' (Gen. 3:16) must not under any condition lead to the 'masculinization' of women." 25

A Christocentric approach demands that one accept the reality of salvation as a norm that requires that a person overcome original sin and not strengthen it. $^{26}$

\section{St. Paul's Writings}

The paraphrased texts of St. Paul the Apostle's Letters cause people to be confused, doubtful, and suspicious of the Church. Many people think that the Church promotes inequality between men and women and a patriarchal model of marriage based on St. Paul's words. The question arises whether one can reconcile Jesus' merciful gaze with St. Paul's strict command: "For the husband is head of his wife just as Christ is head of the church, he himself the savior of the body. As the church is subordinate to Christ, so wives should be subordinate to their husbands in everything" (Eph. 5:23-24) or with the prohibition: "I do not permit a woman to teach or to have authority over a man. She must be quiet"(1 Tim. 2:12).

Two parallel interpretations of St. Paul's writings should be mentioned here. The first interpretation situates St. Paul's teaching in the time in which it was written and, consequently, emphasizes his innovation and courage. For, St. Paul does acknowledge that men should respect women, pray with them, and give them high positions in the Church. Those who defend St. Paul point out that his command that husbands love their wives and be responsible for their wives' spiritual development was something new for that time. In addition, St. Paul acknowledged the need for women to receive formation; ${ }^{27}$ he indicated that women can remain virgins,${ }^{28}$ which was also something new in

\footnotetext{
25 John Paul II, MD, 10.

26 See A. Kostka, "Niepokalana-kobiecość na nowo pisana," 44.

27 See Titus 2:10-11.
}

28 See 1 Corinthians 7:29, 31-35. 
light of Jewish tradition; and he spoke about the value of spiritual motherhood. ${ }^{29}$ The second interpretation emphasizes the Church's use of St. Paul's words in its doctrine and in its practical approach to women. In this sense, Emanuela Meyer, a representative of the intelligensia during the inter-war period, notes: "The First Letter to the Corinthians became a bronze shield and a battering ram for all those who opposed the liberation of women and the healing of relations in this regard. And if arguments in this sad battle against woman are lacking, then deadliest bullet will be cast, and in this way, by literally quoting Scripture, men will find the protective shafts and walls behind which they can safely hide." 30

Needless to say, there is a certain discrepancy between Jesus' teaching and St. Paul's teaching. On the one hand, interpreters should not fall into the error of ahistoricism, which omits the fact that the St. Paul's epistles were written to specific local communities in response to their problems two thousand years ago. Even though St. Paul's way of thinking was progressive at the time, he was still the product of the culture and time in which he lived; therefore, unlike Jesus who is God, St. Paul was unable to completely reject the social norms of his day. On the other hand, interpreters must also consider St. Paul's subjective situation: he was a zealot and a well-educated Jew. As such, he was familiar with Hellenic culture in which women, like Jewish women, had no personal rights but, unlike Jewish women, often led rather dissolute lifestyles. Therefore, in order for an Orthodox Jew like St. Paul to fully accept Jesus' radical teaching, it was undoubtedly necessary for him to undergo the very long and often difficult process of conversion. Therefore, the statement: "When Christ speaks of woman, he announces her redemption and deliverance; he brings peace. However, when Paul speaks, one clearly senses the influence of Moses' views," is justified. ${ }^{31}$

God's Mercy elevates and sees in woman a person who is equal to man not only politically but also familially. Rev. Jarosław Kupczak believes that "The argument that [husbands and wives] should mutually submit to each other makes it possible to properly understand the following version of the text: 'Wives should be subordinate to their husbands as to the Lord' (Eph. 5:22). The Pope opposes any interpretation of this text that suggests that women are less significant than

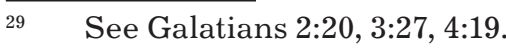

$30 \quad$ P. Ketter, Chrystus a kobiety, 97.

31

Ibid, 19. 
men." 32 In this sense, St. John Paul II wrote: "The apostolic letters are addressed to people living in an environment marked by that same traditional way of thinking and acting. The 'innovation' of Christ is a fact: it constitutes the unambiguous content of the evangelical message and is the result of the Redemption. However, the awareness that in marriage there is mutual 'subjection of the spouses out of reverence for Christ,' and not just that of the wife to the husband, must gradually establish itself in hearts, consciences, behavior and customs. This is a call which from that time onwards, does not cease to challenge succeeding generations; it is a call which people have to accept ever anew." ${ }^{33}$ If the Church presented a unified intepretration of St. Paul's writings on marriage and the mutual relationship between a husband and wife in marriage, then this could help prevent not only individual errors but also misinterpretations of the biblical message on marriage and the family. The world needs to clearly hear that God was the first to fully appreciate and love women, and the history of Salvation unequivocally confirms this truth.

\section{Women as Instruments of Divine Mercy Towards the World}

When expressing his concern for the Samaritan woman at Jacob's well; helping the woman caught in adultery or St. Peter's mother-inlaw; and showing his love, friendship, and respect for Martha and Mary, Jesus included women among his followers and, therefore, became the first and most important person to promote an appreciation of women in the world. The God-Man included women in His mission to bring mercy to the world-a Divine Mercy that took on the face of Jesus and Mary.

Women's predispositions to reveal and realize Divine Mercy arise from their very nature, not in terms of their genetic code, but in terms of their special sensitivity to persons which Pope John Paul II calls the "feminine genius" and of their call to motherhood.

\section{Motherhood}

Since they are co-responsible for humanity, mothers are instruments of Divine Mercy and a challenge to the world. Motherhood distincly

\footnotetext{
32 J. Kupczak, Dar i komunia: Teologia ciała w ujęciu Jana Pawła II (Cracow: Wydawnictwo Znak, 2006), 134. 
shows how Divine Mercy is relational; for, God, in his Mercy, cooperates with-and does not replace-man in bringing new people to life. God loves, but He does not replace parental love. Although motherhood is always valuable because it is the manifestation of a woman's cooperation in the creation of new souls that will exist for all eternity, motherhood does not find fulfillment only physically but also spiritually. The Mother of Christ is the perfect example of physical and spiritual motherhood that, as St. John Paul II pointed out, manifests itself in "Mary's solicitude for human beings, her coming to them in the wide variety of their wants and needs." 34

At the same time, the Holy Father emphasized the "deep understanding" that exists between Jesus and Mary as well as the "mystery of their intimate spiritual union." 35 The pro-life position should not only oppose abortion but also social and familial systems that harass, incriminate, and destroy parents' good relationships with their children. In every case, even the most difficult, the path of motherhood is one of mercy. For, motherhood is the school through which children learn about God's love and his closeness to each person, especially during the earliest stages of their lives when they are completely helpless and dependent on the merciful love of another. In order to be fully implemented and realized in a spiritual sense, motherhood requires the necessary spiritual means and help. This, therefore, is a call to priests to offer convenient Mass options, such as at 7:00 or 8:00 $\mathrm{AM}$ or 6:00 PM, for mothers with young children (and without the help of relatives or friends) who cannot attend Mass; to offer childcare (many youth groups can help in this area) so that mothers with young children can go to the Sacrament of Confession; to provide spiritual guidance to help mothers face, cope with, and even overcome the difficulties of motherhood; and to bless mothers and their babies in utero in order to emphasize the value of human life, to point out importance of birth, and to provide real help and grace during the difficulties and dangers of giving birth. In addition, many mothers struggle with loneliness. In a time when computers dominate social interaction, many mothers feel isolated because they spend months and even years just with their children without very much adult interaction. Therefore, social groups and other forms of support are necessary for women to receive a much-needed break. Like the women of the Bible, women who have been shown mercy will most often be the instruments of mercy in the world.

$34 \quad$ John Paul II, RM, 21.

35 Ibid. 


\section{The Feminie Genius}

The feminine genius is the aspect of the feminine nature that is particularly close to Divine Mercy. More specifically, it is the the particular sensitivity of a woman that Pope John Paul II defined as her "moral and spiritual strength" that arises from a "[woman's] awareness that God entrusts the human being to her in a special way." 36

Women run countless nursuries, kindergartens, orphanages, hospices, hospitals, and centers for people with a variety of disabilities. Mostly women, who are committed to Jesus and his work, perform these acts of mercy toward the world. It is here that man's noble capacity for selfless service is realized. In this sense, John Paul II taught: "In transforming culture so that it supports life, women occupy a place, in thought and action, which is unique and decisive. It depends on them to promote a 'new feminism' which rejects the temptation of imitating models of 'male domination,' in order to acknowledge and affirm the true genius of women in every aspect of the life of society, and overcome all discrimination, violence and exploitation." 37

Equally committed and greatly effective, women have a place in the organization of project management and institutions. The feminine style of leadership is invaluable in the mission and work of transforming culture. The founder of the Schoenstatt Apostolic Movement, Joseph Kentenich, saw that the predisposition of the heart in the feminine style of leadership was indispensible; for, women communicate with and nurture all members of an organization or team. In contrast to the feminine style of leadership, we often see a more militarized, masculine style ${ }^{38}$ that is considered less effective even from the perspective of modern management techniques. Feminine leadership was and is often still lacking in both society and the Church. The presence of women in these areas contributes to a greater humanization of the world. Promoting women in the Church's structures and institutions requires not only the example of Jesus, the Supreme Summit, but also common sense. In fact, during the past 25 years that Catholic radio has existed in Poland, no woman has been the head of any of the country's approximately 30 Catholic radio stations. Only one Curia in Płock has a female spokesperson. It is rare to find a woman on any of the Polish Episcopate's committees, councils, or teams. If a woman is

\footnotetext{
$36 \quad$ John Paul II, MD, 30.

37 John Paul II, Evangelium Vitae, 99. 
present, then she is typically only there as an advisor. ${ }^{39}$ However, more and more structures, organizations, and institutions in the Church are becoming open to change. From year to year, women have greater access to councils and commissions. These changes are occurring in a way proper to the Church: very slowly but increasingly more visibly.

\section{Conclusion}

This article demonstrates that woman, as one who shows God's Divine Mercy to the world, has an honorable and unique place in God's plan. In order to help modern man imitate Christ more faithfully, it is necessary for theologians to update interpretations of certain biblical texts as well as the field of Mariology. Christ through Mary indicates the spiritual task of women. St. John Paul II said that the figure of Mary testifies to the great respect that God has for women-that "it gives men and women the opportunity to discover dimensions of their fate that they have not yet perceived." ${ }^{40}$

As we see in the biblical passage about the wedding in Cana, Mary is active and supportive. As such, she stands as a challenge to the modern world, especially to Christians, by whom the paradigm of the relationship to the world is revealed. Mary, therefore, can change this world; she is the principle on which we base our understanding of the meaning and purpose of our references to God and men. In this context, we can say that Mary is a distinct and unique sign of Divine Mercy towards women and the world. And how we interpret and accept this sign depends on the credibility of the Christian kerygma.

\section{MARYJA JAKO ZNAK BOŻEGO MIŁOSIERDZIA WOBEC KOBIET I ŚWIATA}

Artykuł ukazuje, że w planie Bożego Miłosierdzia Maryja odgrywa jedyną i niepowtarzalną rolę jako Matka Chrystusa. Jednocześnie jest Ona znakiem miłosierdzia Boga wobec wszystkich kobiet i całego świata. W znaku Maryi można bowiem dostrzec podobieństwo do innych kobiet, tak ze względu na płeć jak i na postawę Jezusa wobec napotkanych niewiast. Postawa ta jest na tyle jednoznaczna, że pozwala mówić o szczególnym doświadczeniu Bożego Miłosierdzia przez kobiety i o specyficznym powołaniu kobiet w świecie.

\footnotetext{
39 See P. Ciompa, "Siostry mniejsze, bracia więksi?" in "Fronda" w Sieci 5 (2016): 65. (05.2016).

40 John Paul II, Theology of the Body, s. 271.
} 
Poszczególne rozdziały mówią o Maryi jako o znaku Bożego Miłosierdzia, o Bożym Miłosierdziu wobec kobiet oraz o kobiecie jako niosącej Boże Miłosierdzie wobec świata.

Słowa kluczowe: Maryja, Matka Boga, Boże Miłosierdzie, Wcielenie, macierzyństwo, geniusz kobiecy, egzegeza biblijna.

\section{Bibliography:}

1. Bartosik, G. M. Mediatrix in Spiritu Mediatore: Pośrednictwo Najświetszej Maryi Panny jako uczestnictwo $w$ pośredniczacej funkcji Ducha Świętego $w$ świetle teologii wspótczesnej. Niepokalanow: Wydawnictwo Ojców Franciszkanów, 2006.

2. Brzegowy, T. Pisma Mądrościowe Starego Testamentu. Tarnow: Wydawnictwo Diecezji Tarnowskiej, 2007.

3. Chrostowski, W. "Ludzka cielesność jako obraz Boga." Collectanea Theologica 70, no. 4 (2000): 5.

4. Ciompa, P. "Siostry mniejsze, bracia więksi?" "Fronda" w Sieci, (May 2016): 63-67.

5. De Vaux, R. Instytucje Starego Testamentu. Poznan: Wydawnictwo Pallottinum, 2004.

6. Healy, M. Men and Women are from Eden. E-Book: Kindle. Ohio: Servant Books, 2005. Digital: Kindle.

7. John Paul II. Dives in Misericordia, Encyclical Letter. Vatican City, Italy: Libreria Editrice Vaticana, 1980. http://w2.vatican.va/content/john-paul-ii/ en/encyclicals/documents/hf_jp-ii_enc_30111980_dives-in-misericordia. html

8. John Paul II. Evangelium Vitae, Encyclical Letter. Vatican City, Italy: Libreria Editrice Vaticana, 1995. http://w2.vatican.va/content/john-paul-ii/ en/encyclicals/documents/hf_jp-ii_enc_25031995_evangelium-vitae.html

9. John Paul II. Redemptoris Mater, Encyclical Letter. Vatican City, Italy: Libreria Editrice Vaticana, 1987. http://w2.vatican.va/content/john-paul-ii/ en/encyclicals/documents/hf_jp-ii_enc_25031987_redemptoris-mater.html

10. John Paul II. Letter to Women. Beijing, 1995. https://w2.vatican.va/content/ john-paul-ii/en/letters/1995/documents/hf_jp-ii_let_29061995_women.html

11. John Paul II. Mulieris Dignitatem, Apostolic Letter. Vatican City, Italy: Libreria Editrice Vaticana, 1988. Https://w2.vatican.va/content/johnpaul-ii/en/apost_letters/1988/documents/hf_jp-ii_apl_19880815_mulierisdignitatem.htm

12. John Paul II, The Redemption of the Body and the Sacramentality of Marriage: A Theology of the Body. Catholic Primer: 2006. http://www. catholicprimer.org/papal/theology_of_the_body.pdf

13. Ketter, P. Chrystus a kobiety. Warsaw: Drukarnia Wydawnictwa Ks. Jezuitow, 1937.

14. Kentenich, J. Ideat kobiety: Stereotyp czy pociagajacy wzorzec. OtwockŚwider: Wydawnictwo Apostolicum, 2013. 
15. Kogler, F., Egger-Wenzel R., and Ernst M., eds. Nowy Leksykon Biblijny. Kielce: Wydawnictwo Jedność 2011.

16. Kostka, A. "Niepokalana-Kobiecość na nowo pisana." Kobieta $w$ Kościele i w Społeczeństwie. Studia i Materiaty Wydziatu Teologicznego Uniwersytetu Ślaskiego w Katowicach, no. 78 (2014).

17. Kostka, A. Rozkwitnać petnią barw: Duchowość kobiety w Ruchu Szensztackim. Świder 2008.

18. Kupczak, J. Dar i komunia. Teologia ciała w ujęciu Jana Pawła II. Cracow: Wydawnictwo Znak, 2006.

19. Masciarelli, M.G. Znak Niewiasty: Maryja w Teologii Josepha Ratzingera. Cracow: Wydawnitcwo eSPe, 2008.

20. Salij, J. "Chrześcijański antyfeminizm.” W drodze 343, no. 3 (2002): $125 . \quad$ Mariology

21. Skorowski, H. "Prawa człowieka." In Słownik Społeczny. Edited by B. Szlachta. Cracow: Wydawnictwo WAM, 2004. 